Rather than an iPLEDGE-type registry, Motherisk suggests a mandatory Web-based training program and certification of physicians as a condition for prescribing isotretinoin. A similar program exists for methadone.

In May 2005, Health Canada's Scientific Advisory Panel on isotretinoin unanimously rejecting the idea of an i-PLEDGE type registry for Canada, but otherwise its recommendations were strikingly similar to those measures being taken in the US, including introducing an expanded physicians' checklist, a consent form, a toll-free information number, a Web site, an education program for family doctors and pharmacists, and pregnancy testing.

Dr. Jack Toole, chair of the panel says "There is absolutely no question that pregnancy exposure on isotretinoin must be prevented and that we must do all that we possibly can to do that."

The panel's recommendations have not been acted on. Health Canada spokesperson, Christopher Williams, says the government expects to convene a working group by September to "analyze the best way of putting them into effect. However, it is unlikely that any implementation will take place in 2006."

In April, Health Canada released another advisory about the drug, asking doctors to report any cases of myocardial infarction, cerebrovascular and thromboembolic disorders suspected of being associated with isotretinoin (CMAJ 2006;I74:I2II). Since I983 there have been 29 reported incidents of vascular disorders. Williams said that "no causal link between this type of side effect and the drug has been established."

The drug ranks in the top ro of the US FDA's database of drugs associated with reports of depression and suicide attempts. In Canada, $25 \%$ of adverse responses reported since isotretinoin was introduced relate to psychiatric events. A warning of the possible link was issued in 2001 .

Although it is intended as a drug of last resort for extreme cases of acne, isotretinoin is increasingly being used for milder cases, as well as for psoriasis rosacea and other conditions. - Margot Andresen, Gatineau, Quebec

DOI:I0.1503/cmaj.06053I

\section{News @ a glance}

US abortion bans: South Dakota banned abortion in February, and II other states are poised to consider similar action. "People are afraid here," Dr. Marivin Buehner told the St. Louis Post-Dispatch. Buehner's Rapid City office was picketed after he spoke on TV against the ban. "The whole environment of intimidation that is the legacy of the anti-abortion movement has a stronghold here in South Dakota. That's how the ban got through the Legislature without a challenge from the South Dakota Medical Association." The law is slated to come into effect July I, but Planned Parenthood has vowed to block it through a federal lawsuit. Opponents of the law are also collecting signatures calling for a plebiscite on the ban in November. Similar laws are being considered by governments in Alabama, Georgia, Indiana, Kentucky, Ohio, Mississippi, Missouri, Rhode Island, South Carolina, Tennessee and West Virginia. In related news, the Guttmacher Institute, a not-for-profit corporation for reproductive research, policy analysis and public education, reports that 33 states have made it more difficult or more expensive for poor women and teenagers to obtain contraceptives and related medical services.

Michener finalist: $C M A J$ was shortlisted for the Michener Award for Meritorious Public Service in Journalism for its article on barriers to accessing Plan $B$ (CMAJ 2005;173:I435-6). The 6 finalists for the award included the Globe and Mail, which won for 2 series of articles about breast cancer. The $C M A J$ article, by Laura Eggertson and Barbara Sibbald, informed women about their right to obtain this emergency contraceptive without giving their names and addresses and other personal information to pharmacists, alerted privacy commissioners to this unnecessary practice and, in the end, lowered barriers to access for women in Ontario and, quite likely, in BC and Saskatchewan as well. Ontario Privacy Commissioner Ann Cavoukian said "I applaud you for raising this issue. I can't thank you enough, because it wouldn't have come under anyone's radar screen if you hadn't done this." This is the second year that

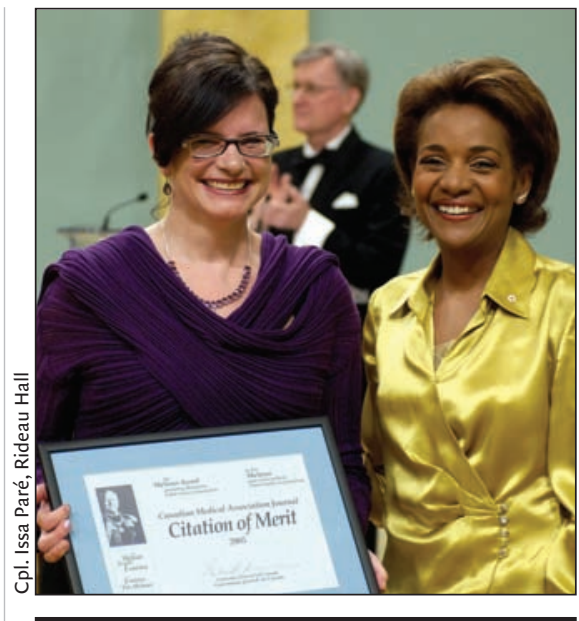

Governor General Michaëlle Jean (right) presents Barbara Sibbald, CMAJ Associate Editor, News, with the journal's Michener Citation of Merit (see news item below).

CMAJ's news department has been short-listed for the award, Canada's highest honour for journalism.

Free Nepali MDs: Physicians for Global Survival (Canada) is urging physicians to sign a petition calling for the freeing of 7 Nepali physicians. The physicians, including Mahesh Masky, the vice president of International Physicians for the Prevention of Nuclear War, were arrested Apr. 8 after peacefully protesting against the Nepali regime and defying the imposed curfew. On Apr. Io, 20 medical students were also arrested; 2 were held at least 48 hours and beaten while in police custody. Health professionals have also been threatened for treating people injured during protests. Article 9 of the Universal Declaration of Human Rights, which Nepal is party to, strictly prohibits the arbitrary arrest and prolonged detention without charge of all persons. Amnesty International, Human Rights Watch and the International Commission of Jurists have called for sanctions against the current regime's violation of human rights. Canadian physician Dr. Neil Arya and Dr. Sonal Singh started the online petition calling for the release of the physicians. - Compiled by Barbara Sibbald, $C M A J$

DOI:Io.I503/cmaj.060530 